\title{
Centrality of Religiosity and Sense of Coherence: a Cross-sectional Study with Polish Young, Middle and Late Adults
}

\author{
Beata Zarzycka \& Elżbieta Rydz \\ Institute of Psychology, The John Paul II Catholic University of Lublin, Poland \\ Correspondence: Beata Zarzycka, The John Paul II Catholic University of Lublin, Institute of Psychology, Al. \\ Racławickie 14, 20-950 Lublin, Poland.
}

\author{
Received: February 11, 2014 Accepted: February 25, 2014 Available online: March 26, 2014 \\ doi:10.11114/ijsss.v2i2.346 \\ URL: http://dx.doi.org/10.11114/ijsss.v2i2.346
}

The research presented in this article was financed by the Ministry of Science and Higher Education within the individual grant No. N N106 227636.

\begin{abstract}
The relationship between religiosity and mental health is a relatively common topic in psychology of religion. Many studies have been performed examining this topic and the results have reported both positive and neutral and even negative relationships between religious commitment and mental health. The ambiguous findings may be due to the fact that religion has a multifaceted nature and different aspects of religiosity are differentially related to mental health. Depending on which definitions of religiosity researchers used, evidence could be supporting a positive or negative relationship between religiosity and mental health and supporting the position that there is no relationship.

The present study aims to examine interactions of five dimensions of religiosity (Intellect, Ideology, Private Practice, Religious Experience, Public Practice) with sense of coherence in Polish adults' sample, separately in women and men in early, middle and late adulthood. Six hundred thirty-six Polish Catholics, 332 women and 304 men, aged between 18 and 79 participated in the research. We applied the Centrality of Religiosity Scale (CRS) by S. Huber and the Sense of Coherence Scale (SOC-29) by A. Antonovsky. The results suggest that the salutogenic function of religiosity is related to age and gender. We noted positive relationships between religiosity and SOC in middle-aged men and in female young and late groups. Implications for intervention are discussed.
\end{abstract}

Keywords: sense of coherence, religiosity, health

\section{Introduction}

The relationship between religiosity and mental health is a relatively common topic in psychology of religion (Mueller, Plevak, \& Rummans, 2001). Many studies have been performed examining this topic and the results have been varied. The majority of empirical data have suggested that religious commitment promotes health (e.g. Koenig \& Larson, 2001; Koenig, McCullough, \& Larson, 2001; Mueller et al., 2001; Seybold \& Hill, 2001; Koenig, 2009). Religious commitment correlated positively with: good frame of mind, existential coherence (Ellison, 1991; Saraglou, 2002; Piedmont, 2005), life-satisfaction (Zwingmann, 1991), personal adjustment (Koenig, Kvale, \& Ferrel, 1988; Watson, Morris, \& Hood, 1994), and self-control (Bergin, Masters, \& Richard, 1987).

However, there are researchers who believe that the support for the positive relationship between religiosity and health is weak and unconvincing (Sloan \& Bagiella, 2002). Some of them have found religiosity to be negatively correlated with health (e.g. Schaefer, 1997), and some have found no significant relationships at all (e.g. Lewis, Lanigan, Joseph, \& Fockert, 1997).

The reviews and meta-analyses done in the mid-1980s to early 1990s (e.g. Payne et al., 1991; Gartner, Larson, \& Allen, 1991) reported both positive and neutral and even negative relationships between religious commitment and health (Gartner, Larson, \& Allen, 1991; Payne et all, 1991). In Larson`s et all (1992) meta-analysis of the 50 studies that reported relationships between religiosity and mental health, 36 reported positive effects of religion on mental health, eight reported a negative effect, and six reported a neutral relationship between religiosity and mental health. The authors concluded that the ambiguous findings may be due to the fact that religion has a multifaceted nature, and they called for specificity in how psychologists operationalize religion. It is possible that different aspects of religiosity are differentially 
related to mental health (Larson et al., 1991; cf. Hackney \& Sanders, 2003; Seeman, Dubin, \& Seeman, 2003).

Following this suggestion Hackey and Sanders (2003) revealed how religiosity and health definitions interact, producing a pattern in which different dimensions of religiosity (institutional, ideology, personal devotion) demonstrate different relationships with mental health. Hackney and Sanders (2003) concluded that depending on which definitions of religiosity researchers used, evidence could be supporting a positive or negative relationship between religiosity and mental health and supporting the position that there is no relationship. Using institutional religiosity as the defining characteristic produces the weakest (and the only negative) correlations across the board, with ideology producing stronger effects, and personal devotion producing the correlations of greatest magnitude.

The present study aims to examine interactions of five dimensions of religiosity (Intellect, Ideology, Private Practice, Religious Experience, Public Practice) with sense of coherence (SOC) in Polish adults' sample, separately in women and men in early, middle and late adulthood. The reason why we decided to conduct this study was that a majority of published studies in this field have used Western, English-speaking samples. Inasmuch as the field of psychology of religion is in a state of rapid growth, there is a need to use samples derived from countries with different cultural backgrounds to carry out cross-cultural comparison, and to test the generalisability of these results (c.f. Abdel-Khalek, 2010). Furthermore, religiosity may have different meanings and role in such a traditionally religious environment as Poland in relation to the Western Christian societies.

\subsection{Religiosity}

Many general measures of religiosity refer either to its intensity, salience, importance, centrality or to various religiosity dimensions, e.g. ideology, private practice, attendance at religious services. Most common are single item scales asking for a self report on the subjective importance of religion, e.g. To what extent are you religious? or How important is your religion for your life? (cf. Tagay et al., 2006). The validity of one-item scales is debatable, because it remains unclear which criteria a respondent assesses in order to produce the response. The answer might have been generated based e.g. on belief, private religious practice or interest in religious questions. Multidimensional measures do not address the general importance of religion for the individual and relation between the postulated multidimensional structure of religiosity often remains unclear (S. Huber \& O. Huber, 2012).

Huber`s model of religiosity includes also the general importance of religion for an individual and theoretical defined five dimensions of religiosity which can be considered as a representative for the total of religious life. It refers to the multidimensional model of religion by Charles Glock (Glock \& Stark, 1965) and the perspective of personality psychology inspired by ideas of Allport and Ross (1967) and Kelly (1955).

Glock's approach is originated in sociology of religion. He defined five dimensions of religion constituting a general frame of reference for empirical research: Intellect, Ideology, Private Practice, Religious Experience and Public Practice (Stark \& Glock, 1970). The five core dimensions, while being developed from a sociological perspective, do also cover religiosity from a psychological perspective as they denote distinguishable psychological modes of the representation of religious contents. Intellect and Ideology refer to thought, Public Practice and Private Practice refer to action, and Religious Experience to emotion and perception (S. Huber \& O. Huber, 2012).

According to Huber (2003) the concept of the personal religious construct-system is the unifying psychological entity in which the core dimensions merge. Referring to Kelly`s (1995) personality theory, a personal construct is an inner representation of world, a template of meaning which makes the anticipation of events possible and structurizes human experiences and behaviors. The personal system of religious constructs can be defined as a superstructure in personality which consists of all personal constructs related to the individual religiosity. A personal religious construct is activated when an individual anticipates something with a religious meaning. Consequently, the five core dimensions can be seen as channels or modes in which personal religious constructs are shaped and activated. The activation or religious constructs in personality can be regarded as a valid measure of the degree of religiosity of the individual (S. Huber \& O. Huber, 2012).

\subsection{Sense of Coherence}

Traditionally, health research in the biomedical paradigm has focused on seeking and understanding of factors that lead to ill-health, and developing ways to prevent or remedy the effects of such pathogenic factors. A contrasting approach is found in salutogenesis, an approach to health theory that focuses on the identification and promotion of ways in which health can be recovered, maintained, or enhanced (Tsuno \& Yamazaki, 2007).

Sense of Coherence (SOC), a core concept of salutogenic theory, is posited by Antonovsky $(1979,2005)$ to be a crucial variable in the alleviation of stress and the maintenance of health. SOC is a global approach to life or underlying personality characteristic that expresses the extent to which one has a pervasive, enduring though dynamic feeling of confidence that: 
1) the stimuli deriving from one's internal and external environments in the course of living are structured, predictable and explicable (Comprehensibility);

2) the resources are available to one to meet the demands posed by these stimuli (Manageability);

3) these demands are challenges, worthy of investment and engagement (Meaningfulness).

SOC arises as a result of experiences gathered in childhood, adolescence, till the early adulthood when an individual becomes relatively stable. Researchers observed that SOC was strongly linked to both physical and mental health outcomes (e.g. Bengel, Strittmatterm, \& Willmann, 1999). These relationships were observed regardless of age, gender, ethnic descent and nationality (Antonovsky, 1993; Eriksson \& Lindstrom, 2006). Some authors consider these results as the empirical support for the thesis that SOC promotes health (Tagay et al., 2006).

\subsection{Research Problem}

According to Antonovsky (1993), systems of socio-cultural beliefs are significant predictors of how SOC is formed. Religious traditions may also have the function of such systems as they provide structures and motives which can multiply the number of potential way of coping with difficult situations (Berger, 1967; Pargament, 1990). However, religion matters more or differently in different sectors. Various kinds of religious experiences characterize differently placed social groups and these religious experiences have different consequences for the young and the aged, for women and men, for lower and higher socioeconomic-status respondents (cf. Jones, 2004; Arévalo, Prado, \& Amaro, 2008; Simpson, Cloud, Newman, \& Fuqua, 2008; Seeman, Dubin, \& Seeman, 2003). Moreover, the results of the studies conducted by the Bertelsman's Foundation (Zarzycka, 2009) on a representative adult sample indicated clearly that, in the Polish sample, the role of religiosity varies according to age and gender. In this respect, we decided to focus on specialized groups - this is why we recruited three different male and female Catholic samples in the early, middle, and late adulthood. Next, following the suggestion of Huckney and Sanders (2003), we assumed that religiosity will be treated multidimensionally — this is why we applied the Huber's model (2003).

This study has three-fold aims: (1) to explore the sex- and age-related differences on the study variables, (2) to examine the correlations between religiosity and SOC among three age groups, (3) to analyze patterns of relations between two sets of variables. Three hypotheses were formulated as follows:

1) Sex- and age-related differences in religiosity and in sense of coherence would be significant between the groups.

2) There should be positive correlations between religiosity (Centrality, Intellect, Ideology, Private Practice, Religious Experience, Public Practice) and Sense of Coherence (SOC, Comprehensibility, Manageability, and Meaningfulness),

3) Based on the results of the bivariate correlational analysis, we also wanted to extract patterns of correlations.

\section{Method}

\subsection{Participants and Procedure}

Six hundred and thirty-six individuals took part in the research, 332 women and 304 men, aged between 18 and 76 years. The mean age of all participants was $41.70(\mathrm{SD}=16.79)$. The young age group ranged from 18 to 30 years $(\mathrm{M}=$ 22.02; $\mathrm{SD}=2.74)$, the middle age group from 31 to 50 years $(\mathrm{M}=42.93 ; \mathrm{SD}=5.13)$ and the old age group ranged from 51 to $79(\mathrm{M}=60.86 ; \mathrm{SD}=6.24)$. Among all respondents, 615 individuals $(96.7 \%)$ declared their religious affiliation as Catholic (compared to approx. 95\% in the general Polish population [Zarzycka, 2009]). Other individuals represented following religious affiliations: Orthodox $(\mathrm{N}=6)$, Protestant $(\mathrm{N}=2)$ and Jehovah`s Witnesses $(\mathrm{N}=3)$. Eight people declared themselves as atheists and 2 people did not declare any religious affiliation. Only Catholics were included in the analysis. Table 1 shows demographic characteristics of each group.

Table 1. Demographic characteristics

\begin{tabular}{|c|c|c|c|c|c|c|c|c|c|c|c|c|c|c|}
\hline \multirow{3}{*}{ Groups } & \multicolumn{6}{|c|}{ Number } & \multicolumn{6}{|c|}{ Education } & \multirow{2}{*}{\multicolumn{2}{|c|}{ Age }} \\
\hline & \multicolumn{2}{|c|}{ Total } & \multicolumn{2}{|c|}{ Women } & \multicolumn{2}{|c|}{ Men } & \multicolumn{2}{|c|}{ Primary } & \multicolumn{2}{|c|}{ Secondary } & \multicolumn{2}{|c|}{ Higher } & & \\
\hline & $\mathrm{N}$ & $\%$ & $\mathrm{~N}$ & $\%$ & $\mathrm{~N}$ & $\%$ & $\mathrm{~N}$ & $\%$ & $\mathrm{~N}$ & $\%$ & $\mathrm{~N}$ & $\%$ & M & SD \\
\hline $18-30$ & 220 & 34.6 & 115 & 34.6 & 105 & 34.5 & 10 & 4.5 & 147 & 66.8 & 63 & 28.6 & 22.02 & 2.74 \\
\hline $31-50$ & 203 & 31.9 & 103 & 31.0 & 100 & 32.9 & 7 & 3.4 & 105 & 51.7 & 91 & 44.8 & 42.93 & 5.13 \\
\hline $51-79$ & 213 & 33.5 & 114 & 34.3 & 99 & 32.6 & 33 & 15.5 & 124 & 58.2 & 56 & 26.3 & 60.86 & 6.24 \\
\hline Total & 636 & 100.0 & 332 & 100.0 & 304 & 100.0 & 220 & 100.0 & 203 & 100.0 & 213 & 100.0 & 41.70 & 16.79 \\
\hline
\end{tabular}

The study was a part of the project titled "Centrality and contents of the religious constructs' system versus sense of coherence", carried out as a grant funded by the Polish Ministry of Science and Higher Education. The research in 2009 and 2010 was conducted by the 8th-term students of psychology at the John Paul II Catholic University of Lublin as a 
part of the courses Psychology of Religion and Developmental Psychology. In 2009 the project included surveys among women and it was supplemented in 2010 by the male sample. Each student surveyed 3 adults (women or men respectively) representing 3 stages of adulthood: early (18-30 years of age), middle (31-50) and late (51 and older). The students could get additional credits for accomplishing this task.

Each respondent filled out a set of tests which encompassed 3 methods for the measurement of religiosity and 1 method for the analysis of sense of coherence, with the following order: Huber`s Centrality of Religiosity Scale, Huber`s Emotion towards God Scale, Hutsebaut`s Post-critical Beliefs Scale and Antonovsky`s Sense of Coherence Scale. This paper is based on the relationships between CRS and SOC-29.

\subsection{Measures}

\subsubsection{Centrality of Religiosity Scale (CRS)}

CRS is a measure of the centrality, importance or salience of religious constructs in personality. It has been developed by Huber (2003) and has yet been applied in more than 100 studies in sociology of religion psychology of religion in 25 countries with in total more than 100,000 participants (S. Huber \& O. Huber, 2012).

CRS operationalizes Glock`s five core dimensions of religiosity with items that measure either the objective or subjective frequency, or the intensity of the activation of personal religious constructs specific to the modi of the dimension. For religious practices, as they are undertaken regularly in most religious traditions and are easily accessible in frequency format, objective frequencies are asked. For events that may occur less regularly (e.g. thinking about religious issues or feeling that God or something divine intervenes in one`s life?) subjective frequencies are asked in five levels (never, rarely, occasionally, often, and very often). The different frequency formats require the recoding of the objective frequencies into five levels of the subjective frequencies (S. Huber \& O. Huber, 2012).

The CRS consists of 15 items divided into five subscales, three items per subscale (S. Huber \& O. Huber, 2012; see also Zarzycka, 2007):

1) Intellect - themes of interest, hermetical skills, styles of thought and interpretation, bodies of knowledge. A general indicator for this dimension is the frequency of thinking about religious issues (e.g. How often do you think about religious issues?, How interested are you in learning more about religious topics?). It indicates how often religious contents are "updated" through the medium of thinking, which leads into the heart of the intellectual dimension.

2) Ideology - beliefs, unquestioned convictions and patterns of plausibility. General indicators of this dimension focus on the aspect of the plausibility of the existence of a transcendent reality, e.g. "To what extent do you believe in the existence of God or something divine?".

3) Private Practive - patterns of action and a personal style of devotion to the transcendence. It focuses both on prayer and meditation, because they express basic and irreducible forms of addressing oneself to transcendence.

4) Religious Experience - patterns of religious perceptions, a body of religious experiences and feelings. It takes into consideration two basic forms of experiencing the transcendence: "one-to-one experiences" which correspond to a dialogical spirituality pattern and "experiences of being at one" corresponding to a participative one.

5) Public Practice - patterns of action, a sense of belonging with respect to a certain social body as well to a certain ritualized imagination of the transcendence. This dimension expresses the frequency and subjective significance of the participation in public religious services and provides information on how much individual religiosity is rooted socially (e.g. How often do you take part in religious services?, How important is it for you to be connected to a religious community?).

The total result (Centrality) is the sum of the subscales' results. High score in the total result means a high level of Centrality and, respectively, high score in the subscale means a high level of its dimension.

In the present study, we applied the authorized adaptation of the CRS scale by Zarzycka (2007, 2011). In adaptation studies, the author observed high discriminative power of items $(0.70 \leq \phi \geq 0.92)$, high reliability and validity (Zarzycka, 2011). For the present sample, the Cronbach's $\alpha$ for the Centrality was 0.94 , and for the subscales the coefficients were as follows: 0.81 for Intellect $(\mathrm{M}=3.11$; $\mathrm{SD}=0.87), 0.89$ for Ideology $(\mathrm{M}=4.36 ; \mathrm{SD}=0.81), 0.87$ for Private Practice $(\mathrm{M}=3.89 ; \mathrm{SD}=0.97), 0.86$ for Religious Experience $(\mathrm{M}=3.17 ; \mathrm{SD}=0.93)$ and 0.80 for Public Practice $(\mathrm{M}=3.89$; $\mathrm{SD}=0.93)$.

\subsubsection{Sense of Coherence Scale (SOC-29)}

We measured sense of coherence (as characterized by the dimensions of Comprehensibility, Manageability, and Meaningfulness) by the 29-item version of the Sense of Coherence Scale (SOC-29, Antonovsky, 1993). Comprehensibility was measured by eleven items (e.g., "Do you have the feeling that you are in an unfamiliar situation 
and don't know what to do?"). We assessed Manageability with ten items (e.g., "How often do you have feelings that you're not sure you can keep under control?"), and finally, Meaningfulness by eight items (e.g., "How often do you have the feeling that there's little meaning in the things you do in your daily life?"). The response scale is a 7-point semantic differential scale, in which the response options range from 1 (very seldom or never) to 7 (very often). Thirteen of the items were reverse scored, so that a low score on each item indicated a high level of Comprehensibility, Manageability, or Meaningfulness.

For the present sample, the Cronbach's $\alpha$ for the SOC was $0.88(\mathrm{M}=4.47$; $\mathrm{SD}=0.75)$, and $\alpha$ in the three subscales were as follows: 0.75 for Comprehensibility $(M=3.97$; $S D=0.82), 0.76$ for Manageability $(M=4.56 ; S D=0.90)$, and 0.79 for Meaningfulness $(\mathrm{M}=5.03 ; \mathrm{SD}=0.98)$.

\section{Results}

First, we compiled descriptive statistics and differences between groups in the analyzed variables. Second, we investigated the relations between CRS and SOC-29 by means of bivariate correlations, and then we conducted a series of canonical analyses to capture a relationship between a set of predictor variables (CRS) and a set of criterion variables (SOC-29). Data from the six groups were analyzed separately.

\subsection{Descriptive Statistics}

Table 2 sets out the mean, standard deviation, and the F ratios (age, sex) for the study variables. Inspection of this table indicates that almost all the $\mathrm{F}$ ratios were significant. For the sake of brevity, Table 3 summarizes these results. Reference to this table shows that the age- and sex-related differences were quite obvious, favouring young men on Sense of Coherence and favouring late adults women on religiosity.

Table 2. Descriptive statistics for women and men in different age groups and differences between age- and sex-groups.

\begin{tabular}{|c|c|c|c|c|c|c|c|c|c|c|c|c|c|c|c|c|}
\hline \multirow{3}{*}{ Variability } & \multicolumn{4}{|c|}{ Young adults } & \multicolumn{4}{|c|}{ Middle-aged } & \multicolumn{4}{|c|}{ Late adults } & \multirow{2}{*}{\multicolumn{2}{|c|}{ Age }} & \multirow{2}{*}{\multicolumn{2}{|c|}{ Sex }} \\
\hline & \multicolumn{2}{|c|}{ Women } & \multicolumn{2}{|c|}{ Men } & \multicolumn{2}{|c|}{ Women } & \multicolumn{2}{|c|}{ Men } & \multicolumn{2}{|c|}{ Women } & \multicolumn{2}{|c|}{ Men } & & & & \\
\hline & $\mathrm{M}$ & SD & $\mathrm{M}$ & SD & $\mathrm{M}$ & SD & $\mathrm{M}$ & SD & $\mathrm{M}$ & $\mathrm{SD}$ & $\mathrm{M}$ & SD & $\mathrm{F}$ & $\mathrm{df}$ & $\mathrm{F}$ & $\mathrm{df}$ \\
\hline Intellect & 2.76 & 0.79 & 2.75 & 0.84 & 3.22 & 0.81 & 3.05 & 0.78 & 3.64 & 0.82 & 3.20 & 0.82 & $36.55 * * *$ & 2,630 & $10.23 * * *$ & 1,630 \\
\hline Ideology & 4.23 & 0.89 & 4.09 & 0.90 & 4.47 & 0.72 & 4.31 & 0.69 & 4.66 & 0.55 & 4.39 & 0.91 & $11.76 * * *$ & 2,630 & $9.45 * *$ & 1,630 \\
\hline Private Practice & 3.62 & 0.99 & 3.37 & 1.05 & 4.19 & 0.81 & 3.67 & 0.86 & 4.50 & 0.66 & 3.95 & 0.93 & $35.43 * * *$ & 2,630 & $38.74 * * *$ & 1,630 \\
\hline Experience & 3.08 & 0.92 & 2.86 & 1.01 & 3.29 & 0.82 & 2.95 & 0.79 & 3.60 & 0.85 & 3.18 & 0.97 & $12.04 * * *$ & 2,630 & $20.79 * * *$ & 1,630 \\
\hline Public practice & 3.57 & 0.91 & 3.33 & 1.01 & 4.00 & 0.81 & 3.74 & 0.89 & 4.37 & 0.71 & 3.99 & 0.89 & $37.76^{* * *}$ & 2,630 & $18.01 * * *$ & 1,630 \\
\hline CENTRALITY & 3.45 & 0.71 & 3.27 & 0.80 & 3.83 & 0.65 & 3.54 & 0.66 & 4.15 & 0.59 & 3.74 & 0.75 & $37.18 * * *$ & 2,630 & $27.45^{* * *}$ & 1,630 \\
\hline Comprehensibility & 3.67 & 0.82 & 3.96 & 0.66 & 3.87 & 0.87 & 4.11 & 0.78 & 4.09 & 0.89 & 4.20 & 0.81 & $8.65 * * *$ & 2,624 & $10.87 * * *$ & 1,624 \\
\hline Manageability & 4.54 & 0.95 & 4.82 & 0.71 & 4.38 & 0.83 & 4.68 & 0.85 & 4.40 & 1.04 & 4.56 & 0.93 & 2.91 & 2,624 & $11.55 * * *$ & 1,624 \\
\hline Meaningfulness & 5.17 & 0.95 & 5.28 & 0.81 & 4.96 & 0.89 & 5.02 & 1.08 & 4.84 & 1.09 & 4.98 & 1.01 & $6.02 * *$ & 2,624 & 1.71 & 1,624 \\
\hline SOC & 4.38 & 0.77 & 4.62 & 0.61 & 4.35 & 0.70 & 4.56 & 0.78 & 4.40 & 0.85 & 4.54 & 0.76 & 0.23 & 2,624 & $10.30 * * *$ & 1,624 \\
\hline
\end{tabular}

Table 3. The study groups of low versus high mean scores.

\begin{tabular}{lll}
\hline \multicolumn{1}{c}{ Variables } & The group of low mean score & The group of high mean score \\
\hline Intellect & Male young adults & Female late adults \\
Ideology & Male young adults & Female late adults \\
Private Practice & Male young adults & Female late adults \\
Experience & Male young adults & Female late adults \\
Public Practice & Male young adults & Female late adults \\
CENTRALITY & Male young adults & Female late adults \\
\hline Comprehensibility & Female young adults & Male late adults \\
Manageability & Female middle adults & Male young adults \\
Meaningfulness & Female late adults & Male young adults \\
SOC & Female middle adults & Male young adults \\
\hline
\end{tabular}

\subsection{Bivariate Correlations}

Table 4 presents the Pearson correlation coefficients among the six samples. Reference to this table shows that the patterns of correlations between religiosity and sense of coherence dimensions are different in six samples. It is important to note that the greatest number of correlations were in men in the middle-age group (all correlations coefficients were statistically significant). On the other hand, a smaller number of significant correlations we observed in female young and late groups (see Table 4). 
Table 4. Correlation between religiosity (C-15) and Sense of Coherence (SOC-29) for women and men in different age groups

\begin{tabular}{|c|c|c|c|c|c|c|c|c|c|c|c|c|c|}
\hline \multirow{2}{*}{ Sex } & \multirow{2}{*}{ C-15 } & \multicolumn{4}{|c|}{ Age $18-30$} & \multicolumn{4}{|c|}{ Age $31-50$} & \multicolumn{4}{|c|}{ Age $51-79$} \\
\hline & & Compr & Manag & Meanin & $\mathrm{SOC}$ & Compr & Manag & Meanin & $\mathrm{SOC}$ & Compr & Manag & Meanin & $\mathrm{SOC}$ \\
\hline \multirow{6}{*}{$\begin{array}{l}\text { ฮี } \\
\text { है } \\
\text { है }\end{array}$} & Intellect & 0.08 & 0.13 & 0.15 & 0.14 & 0.08 & 0.10 & $0.24 *$ & 0.17 & $0.21 *$ & $0.23^{*}$ & $0.25 * *$ & $0.27 * *$ \\
\hline & Ideology & 0.06 & $0.19 *$ & $0.29 * *$ & $0.21 *$ & -0.03 & -0.02 & 0.06 & -0.03 & 0.04 & 0.06 & 0.12 & 0.07 \\
\hline & Private practice & -0.01 & 0.05 & $0.22 *$ & 0.09 & -0.02 & -0.01 & 0.02 & -0.07 & 0.05 & 0.04 & 0.12 & 0.08 \\
\hline & Experience & -0.01 & 0.08 & $0.24 * *$ & 0.11 & -0.01 & -0.04 & 0.10 & 0.02 & $0.20 *$ & 0.14 & $0.20 *$ & $0.21 *$ \\
\hline & Public practice & -0.02 & -0.04 & 0.04 & -0.01 & 0.02 & 0.06 & 0.06 & 0.05 & 0.13 & 0.10 & 0.14 & 0.14 \\
\hline & Centrality & 0.02 & 0.10 & $0.24 * *$ & 0.13 & 0.01 & 0.02 & 0.12 & 0.05 & 0.16 & 0.15 & $0.21 *$ & $0.20 *$ \\
\hline \multirow{6}{*}{$\stackrel{\bar{e}}{\Sigma}$} & Intellect & -0.01 & -0.04 & 0.05 & -0.04 & $0.24 *$ & $0.25 *$ & $0.33^{* *}$ & $0.31 * *$ & 0.02 & -0.04 & 0.09 & 0.01 \\
\hline & Ideology & 0.02 & 0.01 & 0.12 & 0.06 & $0.22 *$ & $0.38 * * *$ & $0.46 * * *$ & $0.40 * * *$ & 0.05 & 0.11 & 0.18 & 0.13 \\
\hline & Private practice & 0.08 & 0.05 & 0.13 & 0.10 & $0.32 * * *$ & $0.34 * * *$ & $0.48 * * *$ & $0.43 * * *$ & 0.06 & 0.07 & 0.16 & 0.11 \\
\hline & Experience & 0.04 & 0.08 & $0.24 *$ & 0.12 & $0.32 * * *$ & $0.36 * * *$ & $0.42 * * *$ & $0.41 * * *$ & 0.12 & -0.07 & 0.09 & 0.08 \\
\hline & Public practice & 0.06 & -0.01 & 0.03 & 0.03 & $0.28 * *$ & $0.30 * *$ & $0.41 * * *$ & $0.38 * * *$ & 0.15 & 0.14 & 0.16 & 0.18 \\
\hline & Centrality & 0.03 & 0.02 & 0.14 & 0.08 & $0.34 * * *$ & $0.39 * * *$ & $0.50 * * *$ & $0.47 * * *$ & 0.09 & 0.06 & 0.17 & 0.13 \\
\hline
\end{tabular}

Notes: Compr $=$ Comprehensibility; Manag = Manageability; Meanin = Meaningfulness; SOC $=$ Sense of Coherence

$* \mathrm{p}<0.05 ; * * \mathrm{p}<0.01 ; * * * \mathrm{p}<0.001$

In late adult women SOC and its dimensions (Comprehensibility, Manageability, Meaningfulness) correlated with Intellect and Experience (all dimensions but for Manageability, which did not correlate with Experience). Centrality of religiosity correlated with SOC and Meaningfulness. In young adult women Meaningfulness correlated with four CRS scales (Ideology, Private Practice, Religious Experience, Centrality). SOC and Manageability correlated with Ideology.

\subsection{Canonical Analysis}

To investigate a relationship between a set of predictor variables (subscales of CRS) and a set of criterion variables (subscales of SOC-29), we conducted the canonical correlation analysis for each of the six groups separately. The results of this analysis revealed one pair of significantly correlated canonical variables in the group of middle-aged men (see Table 5).

Table 5. Results of canonical correlation between subscales of C-15 and SOC-29 in men aged 31-50.

\begin{tabular}{lr}
\hline & \multicolumn{2}{c}{ Canonical variables } \\
Men [31-50]
\end{tabular}

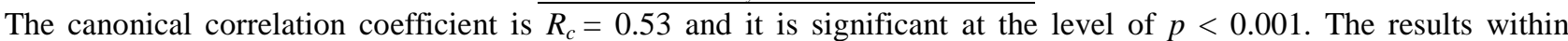
SOC-29 subscales explain the variability in their own set to the extent of $65 \%\left(A d_{x}=0.65\right)$, and, respectively, the results within CRS subscales-63\% $\left(A d_{y}=0.63\right)$. Religiosity explains $19 \%$ of the variance in the SOC subcomponents. In the criteria set, all SOC subcomponents were included in the canonical variable, and all CRS subscales - in the predictor set variable. The correlation signs are positive, therefore the higher religiosity scores, the higher SOC is.

\section{Discussion}

There has emerged an extensive body of empirical work dealing with the relationship between religiosity and physical 
and mental health, mainly on Western participants (review of research see e.g. Hackney, Sanders, 2003). This study was intended to investigate the relationship between religiosity and SOC among six samples of Polish adults. The results of our research make it possible for us to formulate the following conclusions:

1). Sex-related differences were significant on CRS and SOC-29 variables. The differences on CRS favoured women, whereas the differences on SOC-29 favoured men, in all of comparisons.

Thus, the fact that women score higher in religiosity than men does not seem to be surprising. This has been the general conclusion in the social scientific and psychological literature, based on Christian samples (see e.g. Argyle \& Beit-Hallahmi, 1975; Batson, Schoenrade, \& Ventis, 1993; Beit-Hallahmi \& Argyle, 1997; Brown, 1987; Francis, 1993; Paloutzian, 1996). Moreover, an analysis of survey data in Polish representative sample also finds gender is a significant factor. Women pay more attention to religiosity than men, $47 \%$ of women and only $32 \%$ of men exhibited a high centrality of religiosity. Women pray more often, are more likely to believe in God, and are more religious than men in a variety of other ways (Zarzycka, 2009). These differences are considered as a reflection of differences in women's personality and socialization (Beit-Hallahmi \& Argyle, 1997).

However, women tend to have lower SOC scores than men. Antonovsky (2005), although at first considered the sense of coherence concept "universally meaningful" also from a gender perspective, later agreed that SOC probably was gender differentiated with age. A study performed on teenagers did not show any gender differences but studies on adults did. It has been put forward that the female socialization process might be a barrier to the development of a strong SOC (c.f. Larsson \& Kallenberg, 1996; Krantz \& Östergren, 2004).

2). Age-related differences were significant on CRS and SOC-29 variables too. The differences on CRS favoured late adults, whereas the differences on SOC-29 favoured young adults (SOC, Manageability, Meaningfulness). Thus, the result that religiosity becomes more important to both women and men as they grow older, does not seem to be surprising. Longitudinal studies show that adults in the United States generally become more religious as they age (Argue, Johnson, \& White, 1999; Miller \& Nakamura, 1996). An analysis of survey data in a Polish representative sample also finds religion rises in importance as people age. Among 18- to 39-year-olds it is accorded a subordinate role, but one which increases markedly after the age of 40. An even greater acceptance of religion can be seen after the age of 60 (Zarzycka, 2009). Age related increases are connected with life events, namely marriage and child rearing (Ingersoll-Dayton et al., 2002), declines in health (Kelley-Moore \& Ferraro, 2001) and the death of a spouse (Brown, Nesse, House, \& Utz, 2004).

On the other hand, our findings like some of the previous studies (c.f. Krantz \& Östergren, 2004) indicated that a level of SOC is changeable in adult life. This result is not in accordance with the Antonovsky's (1979) claim that SOC is a psychological factor being developed during upbringing and giving rise to a certain fixed individual level of coping ability, as the three components forming the SOC concept (Comprehensibility, Manageability, Meaningfulness) are considered to be constant phenomena in adult life. We suppose that the level of the SOC may be based on the intertwined links between a person and his or her sociocultural setting e.g. a position in the social structure, social network, support, etc. (Krantz \& Östergren, 2004).

3). Each of the six correlation matrices comprises ten variables, that is 144 correlation coefficients all in all. 103 correlations (i.e., 70.14\%) were non-significant. It could suggest that there is not the relationship between religiosity and sense of coherence. But the detailed examination of the correlations' coefficients in each sample revealed varied correlation templates in women and men, in particular age groups. Interestingly enough, in middle-aged men all correlations were significant. Whereas there were a few correlations in women -8 in late adults and 6 in young adults. Therefore, we suppose that the salutogenic function of religion may be related to gender and age, particularly to developmental tasks and the characteristics of social roles in adult women and men (Selman, 1976; Havighurst, 1981; Kegan, 1982).

In women in early adulthood, the identification with religious beliefs seems to be inscribed in nonconformist tendencies and youthful idealism, which are characteristic for this age group. Making an attempt at differing religious phenomena from non-religious ones, ideals from the reality of everyday life, they may form a belief that coherent functioning is possible on the strength of some system, ideal, values - this is probably why the relationship between Ideology and SOC is so strong (Tonsor, 2000; Weaver, 2003). It is notable that the dimension of Ideology played a significant role among the youngest respondents in Religionsmonitor 2008 as well (Zarzycka, 2009).

In middle adult women, the involvement in the fulfillment of social and professional roles seems to be a more integrating factor for the functioning than the relation to beliefs and religious ideals. Women display a stronger involvement in family life and closer community than men, e.g. it is rather adult daughters than adult sons who are carers of elderly parents (Cantor, 1983; Himes, Jordan, \& Farkes, 1996). Women's targets and decisions regarding life are more often related to the family life than it is the case in men (Nurmi, 1996; Rydz \& Ramsz, 2007). The domination of the "social self" over the "universalizing self" in women may be present until late adulthood (Kegan, 1980, 1982) as 
well as determine the extent of the coherence processes (Fowler, 1980). We suppose that in women, till late adulthood, SOC is shaped on the basis of complex social context rather than in relation to universal matters. This is why they do not "discover" the integrating function of religiosity at this stage of adulthood development (cf. Brzezińska, 2000). It is not until late adulthood (51-70), upon the completion of adult life tasks, when they come back to religiosity again. However, it is not Ideology that is the source of SOC at this stage, but the interest in religious issues and personal religious experience.

Men, in turn, reveal a completely different pattern of the salutogenic function of religiosity. It is the strongest in middle adulthood. We suppose it could be related to the task of passing faith to the next generation. In this respect, introducing children, charges and other people to the principles of religion becomes a source for SOC in a man (Cameron et al., 2005). We cannot preclude that the faster development of the "universalizing self" and weaker meaning of the "social self" in men may cause the salutogenic function of religiosity to develop earlier, i.e. in middle adulthood, than in women.

4). The canonical analysis revealed the ways in which religiosity and sense of coherence interact and operate. Centrality of religiosity proved to be a significant predictor of SOC in middle-aged men, i.e. subcomponents of SOC (Comprehensibility, Manageability, Meaningfulness) increase together with the increase in the dimensions of Centrality: Intellect, Ideology, Private Practice, Experience and Public Practice. However, in other samples we have not observed significant patterns of relationships between religiosity and sense of coherence.

Furthermore, the mechanism of relationships between religiosity and SOC may be diversified with regard to gender. In men (31-50), SOC rises together with the increase of the importance (Centrality) of religion. In women, we have not noted such a direct dependency. We assume that the mechanism of the salutogenic religiosity function varies between women and men, i.e. there are different religiosity dimensions responsible for coherence processes in both groups. The results of our earlier studies suggest following such interpretation. For instance, in our study regarding the relationship between Post-Critical Beliefs (PCBS) and SOC, we observed that in men the fact of the acceptance of religious contents itself intensifies the salutogenic function of religiosity but in women, SOC rises together with the increase of the acceptance of religion and its symbolic understanding (Zarzycka \& Rydz, 2013). As the CRS applied in this research includes only the measures of the traditionally defined religiosity, it was impossible to capture the relationships for the female sample in the canonical analysis. Therefore, we suppose that, as for the future research, we should include differentiated measures of religiosity, especially when searching for SOC predictors in women.

Presented explanations are merely a hard effort to structurize the empirical data. There are still an open issue of the generic interpretation of the relationships of the salutogenic function of religion with gender and development stage. We suppose that the observed dependencies may be a result of the interaction of numerous factors, in particular of the measured religiosity aspects and complex development processes. So, their interpretation would require further complex research and testing hypotheses based on the concepts of religious development of an adult — woman and man. The results of the presented research might be helpful in setting further research problems.

Probably the greatest limitation of our research is its cross sectional nature, which does not enable us to follow with causal interpretations. This is, however, a common limitation of cross sectional data. Thus, a longitudinal study may be needed.

\section{Conclusion}

The results of the studies presented in literature are inconsistent in terms of the empirical research on the relationships between religiosity and health. Some authors suggest that religious commitment is correlated with better health outcomes (Mueller at al., 2001). Other researchers believe that the postulated correlations between religiosity and health are unconvincing and weak. (Sloan \& Bagiella, 2002). Next, numerous psychologists describe religiosity as a unidimensional construct and the research with the application of the multidimensional religiosity concept are limited to the division into intrinsic and extrinsic religiosity. This division is, however, criticized on both conceptual and psychometric grounds (Kirpatrick \& Hood, 1990). The multidimensional model of religiosity devised by Huber (2003), has opened new perspectives for studying religiosity-health outcomes relation. In the present study, we analyzed the relationships between Huber's dimensions of religiosity and SOC. The results suggest that the salutogenic function of religiosity is related to age and gender. It is most strongly marked in young and late adulthood in women; in men-in middle adulthood. In men, the increase in SOC coexists with the rise in the Centrality of Religiosity.

\section{References}

Abdel-Khalek, A. M. (2012). Subjective well-being and religiosity: a cross-sectional study with adolescents, young and middle-age adults. Mental Health, Religion \& Culture, 15(1), 39-52. http://dx.doi.org/10.1080/13674676.2010.551324

Allport, G. W., \& Ross, J. M. (1967). Personal religious orientation and prejudice. Journal of Personality and Social Psychology, 5, 432-443. http://dx.doi.org/10.1037/h0021212 
Antonovsky, A. (1979). Health, stress and coping. San Francisco: Jossey-Bass.

Antonovsky, A. (1993). The structure and properties of the SOC scale. Social Science \& Medicine, 36, 725-733. http://dx.doi.org/10.1016/0277-9536(93)90033-Z

Antonovsky, A. (2005). Rozwiktanie tajemnicy zdrowia [Unraveling the secret of health]. Warszawa: Instytut Psychiatrii i Neurologii.

Arévalo, S., Prado, G., \& Amaro, H. (2008). Spirituality, SOC, and coping responses in women receiving treatment for alcohol and drug addiction. Evaluation and Program Planning, 31, 113-123. http://dx.doi.org/10.1016/j.evalprogplan.2007.05.009.

Argue, A., Johnson, D. R., \& White, L. K. (1999). Age and religiosity: Evidence from a three-wave panel analysis. Journal for the Scientific Study of Religion, 38, 423-435. http://dx.doi.org/10.1037/0022-3514.89.1.78

Argyle, M., \& Beit-Hallahmi, B. (1975). The Social psychology of religion. London: Routledge and Kegan Paul.

Batson, C. D., Schoenrade, P. A., \& Ventis, W. L. (1993). Religion and the individual: A social-psychological perspective. Oxford: Oxford University Press.

Beit-Hallahmi, B., \& Argyle, M. (1997). The Psychology of Religious Belief, Behaviour and Experience. London: Routledge.

Bengel, J., Strittmatter, R., \& Willmann, H. (1999). What keeps people healthy? The current state of discussion and the relevance of Antonovsky's salutogenetic model of health. Federal Centre for Health Education, Cologne.

Berger, P. (1967). The sacred canopy: elements of a sociological theory of religion. New York: Doubleday.

Bergin, A., Masters, K., \& Richards, P. (1987). Religiousness and mental health reconsidered: a study of an intrinsically religious sample. Journal of Counseling Psychology, 34, 197-204. http://dx.doi.org/10.1037/0022-0167.34.2.197

Brown, L. B. (1987). The Psychology of Religious Belief. London: Academic Press.

Brown, S. L., Nesse, R. M., House, J., \& Utz, R. L. (2004). Religion and emotional compensation: Results from a prospective study of widowhood. Personality and Social Psychology Bulletin, 30, 1165-1174. http://dx.doi.org/10.1177/0146167204263752

Brzezińska, A. (2000). Społeczna psychologia rozwoju [Social psychology of development]. Warszawa: Wydawnictwo Naukowe Scholar.

Cameron, H., Pallant, E., \& Watchorn, H. (2005). Professional identity, regulation and formation-a review of values in professional practice: lesson for health, social care and other professionals. Contact. The interdisciplinary Journal of Pastoral Studies, 145, 33-41.

Cantor, M. H. (1983). Strain among caregivers. A study of experience in the United States. The Gerontologist, 23(6), 587-604. http://dx.doi.org/10.1093/geront/23.6.597

Ellison, C. (1991). Religious involvement and subjective well-being. Journal of Health and Social Behavior, 32(1), 80-99. http://dx.doi.org/10.5502/ijw.v3i2.5

Eriksson, M., \& Lindström, B. (2006). Antonovsky`s SOC scale and the relation with health: A systematic review. Journal of Epidemiology and Community Health, 60, 376-381. http://dx.doi.org/10.1136/jech.2005.041616

Fowler, J. W. (1980). Faith and structuring of meaning. In Ch. Brusselmans, J. W. Fowler, \& A. Vergote (Eds.), Toward moral and religious maturity (pp. 51-85). New York: Silver, Burdett, Morristown.

Francis, L. J. (1993). Personality and religion among college students in the UK. Personality and Individual Differences, 14, 619-622. http://dx.doi.org/10.1016/0191-8869(93)90159-Z

Gartner, J., Larson, D. B., \& Allen, G. D. (1991). Religious commitment and mental health: A review of the empirical literature. Journal of Psychology and Theology, 19, 6-25.

Glock, C. Y., \& Stark, R. (1965). Religion and society in tension. Chicago: Rand McNally.

Hackney, Ch., \& Sanders, G. S. (2003). Religiosity and Mental Health: A Meta-Analysis of Recent Studies. Journal for the Scientific Study of Religion, 42(1), 43-55. http://dx.doi.org/10.1111/1468-5906.t01-1-00160

Havighurst, R. J. (1981). Developmental tasks and education. New York: Longman and Green.

Himes, C. L., Jordan, A. K., \& Farkas, J. I. (1996). Factors influencing parental caregiving by adult women. Research on Aging, 18, 349-370. http://dx.doi.org/10.1177/0164027596183005

Huber, S. (2003). Zentralität und Inhalt. Ein neues multidimensionales Messmodell der Religiosität [Centrality and content. A new multidimensional measurement model for religiosity]. Opladen: Leske + Budrich. 
http://dx.doi.org/10.1007/978-3-663-11908-1

Huber, S., \& Huber, O. W. (2012). The Centrality of Religiosity Scale (CRS). Religions, 3, $710-724$. http://dx.doi.org/10.3390/rel3030710

Ingersoll-Dayton, B., Krause, N., \& Morgan, D. (2002). Religious trajectories and transitions over the life course. International Journal of Aging and Human Development, 55, 51-70. http://dx.doi.org/10.2190/297Q-MRMV-27TE-VLFK

Jones, J. W. (2004). Religion, health, and the psychology of religion: How the research on religion and health helps us understand religion. Journal of Religion and Health, 43(4), 317-328. http://dx.doi.org/10.1007/s10943-004-4299-3

Kegan, R. (1980). There the dance is: Religious dimensions of a developmental framework. In Ch. Brusselmans, J. W. Fowler, \& A. Vergote (Eds.), Toward moral and religious maturity (pp. 403-440). New York: Silver, Burdett, Morristown.

Kegan, R. (1982). The evolving self. Problem and process in human development. Cambridge, Mass: Harvard University Press.

Kelley-Moore, J. A., \& Ferraro, K. F. (2001). Functional limitations and religious service attendance in later life: Barrier and/or benefit mechanism. Journal of Gerontology: Social Sciences, 56B, S365-S373. http://dx.doi.org/10.1093/geronb/56.6.S365

Kelly, G. (1955). The psychology of personal constructs. New York: Norton.

Kirkpatrick, L. A., \& Hood, R. W. (1990). Intrinsic-extrinsic religious orientation: The boon or bane of contemporary psychology of religion? Journal for the Scientific Study of Religion, 29, 442-462. http://dx.doi.org/10.2307/1387311

Koenig, H. G., McCullough, M. E., \& Larson, D. B. (2001). Handbook of religion and health. Oxford, England: Oxford University Press. http://dx.doi.org/10.1093/acprof:oso/9780195118667.001.0001

Koenig, H., Kvale, J., \& Ferrel, C. (1988). Religion and well-being in later life. Gerontologist, $28,18-28$. http://dx.doi.org/10.1093/geront/28.1.18

Koenig, H. G., \& Larson, D. B (2001). Religion and mental health: Evidence for an association. International Review of Psychiatry, 13, 67-78. http://dx.doi.org/10.1080/09540260124661

Koenig, H. G. (2009). Research on religion, spirituality, and mental health. The Canadian Journal of Psychiatry, 54(5), 283-291.

Krantz, G., \& Östergren, P. (2004). Does it make sense in a coherent way? Determinants of sense of coherence in Swedish women 40 to 50 years of age. International Journal of Behavioral Medicine, 11, $18-26$. http://dx.doi.org/10.1207/s15327558ijbm1101_3

Larson, D. B., Sherrill, K. A., Lyons, J. S., Craigie, E. C., Thielman, S. B., Greenwold, M. A., \& Larson, S. S. (1992). Associations between dimensions of religious commitment and mental health reported in the American Journal of Psychiatry and Archives of General Psychiatry: 1978-1989. American Journal of Psychiatry, 149, 557-59.

Larsson, G., \& Kallenberg, K.O. (1996). Sense of coherence, socio-economic conditions and health. European Journal of Public Health, 6, 175-180. http://dx.doi.org/10.1093/eurpub/6.3.175

Lewis, C. A., Lanigan, C., Joseph, S., \& de Fockert, J. (1997). Religiosity and happiness: No evidence for an association among undergraduates. Personality and Individual Differences, 22, $119-21$. http://dx.doi.org/10.1016/S0191-8869(97)88910-6

Miller, A. S., \& Nakamura, T. (1996). On the stability of church attendance patterns during a time of demographic change. Journal for the Scientific Study of Religion, 35, 275-284. http://dx.doi.org/10.2307/1386559

Mueller, P., Plevak, D., \& Rummans, T. (2001). Religious involvement, spirituality, and medicine: Implications for clinical practice. Mayo Clinic Proceedings, 76(12), 1225-1235. http://dx.doi.org/10.4065/76.12.1225

Nurmi, J. E. (1992). Age differences in adult life goals, concerns and their temporal extension: A life course approach to future-oriented motivation. International Journal of Behavioral Development, 15(4), 487-509. http://dx.doi.org/10.1177/016502549201500404

Paloutzian, R. F. (1996). Invitation to the psychology of religion. (Second edition). Massachusetts: Allyn and Bacon.

Pargament, K. (1990). God help me: toward a theoretical framework of coping for the psychology of religion. Research in the Social Scientific Study of Religion, 2, 195-224.

Payne, I. R., Bergin, A. E., Bielema, K. A., \& Jenkins, P. H. (1991). Review of religion and mental health: Prevention 
and the enhancement of psychosocial functioning. Prevention in Human Services, 9, 11-40. http://dx.doi.org/10.1300/J293v09n02_02

Piedmont, R. (2005). The role of personality in understanding religious and spiritual constructs. In R. Paloutzian, C. Park, (Eds.), Handbook of the psychology of religion and spirituality (pp. 253-273). London: The Guilford Press.

Rydz, E., \& Ramsz, J. (2007). Rozwój celów decyzji życiowo doniosłych w biegu życia człowieka. Empiryczne badanie młodzieży i osób dorosłych [The development of the lifetime aims on the human life's continuum]. In E. Rydz, \& D. Musiał (Eds.), Z zagadnień psychologii rozwoju [From the development issues] Vol. I (pp. 217-234). Lublin: Towarzystwo Naukowe KUL.

Saraglou, V. (2002). Religion and the five-factors of personality: A meta-analytic review. Personality and Individual Differences, 32, 15-25. http://dx.doi.org/10.1016/S0191-8869(00)00233-6

Schaefer, W. E. (1997). Religiosity, spirituality, and personal distress among college students. Journal of College Student Development, 38, 633-44.

Seeman, T. E., Dubin, L. F., \& Seeman, M. (2003). Religiosity/spirituality and health: A critical review of the evidence for biological pathways. American Psychologist, 58(1), 53-63. http://dx.doi.org/10.1037/0003-066X.58.1.53

Selman, R. J. (1976). The development of social-cognitive understanding: a guide to education and clinical practice. In T. Lickona (Ed.), Moral development and behavior. Theory, research, and social issues (pp. 299-316). New York: Holt, Rinehart \& Winston.

Seybold, K. S., \& Hill, P. C. (2001). The role of religion and spirituality in mental and physical health. Current Directions in Psychological Science, 10, 21-24. http://dx.doi.org/10.1111/1467-8721.00106

Simpson, D. B., Cloud D. S., Newman, J. L., \& Fuqua, D. R. (2008). Sex and gender differences in religiousness and spirituality. Journal of Psychology and Theology, 36(1), 42-52.

Sloan, R., \& Bagiella, E. (2002). Claims about religious involvement and health outcomes. Annals of Behavioral Medicine: A Publication of the Society of Behavioral Medicine, 24(1), 14-21. http://dx.doi.org/10.1207/S15324796ABM2401_03

Stark, R., \& Glock, C. Y. (1970). American Piety: The nature of religious commitment. Berkeley, Los Angeles, London: University of California Press.

Tagay, S., Erim, Y., Brähler, E., \& Senf, W. (2006). Religiosity and SOC-protective factors of mental health and well-being? Zeitschrift für Medizinische Psychologie, 15, 165-171.

Tonsor, S. (2000). How does the past become the future? Modern Age. A Quarterly Review, 42, 8-13.

Tsuno, Y. S., \& Yamazaki, Y. (2007). A comparative study of Sense of Coherence (SOC) and related psychosocial factors among urban versus rural residents in Japan. Personality and Individual Differences, 43, 449-461. http://dx.doi.org/10.1186/1471-2458-12-1107

Watson, P., Morris, R., \& Hood R. (1994). Religion and rationality: I. Rational-emotive and religious understandings of perfectionism and other irrationalities. Journal of Psychology and Christianity, 13, 356-372.

Weaver, D. (2003). Taking sin seriously. Journal of Religious Ethics, 31, 45-74. http://dx.doi.org/10.1111/1467-9795.00122

Zarzycka, B. (2009). Tradition or charisma-Religiosity in Poland. In: Bertelsmann Stiftung (Ed.) What the world believes: Analysis and commentary on the Religion Monitor 2008 (pp. 201-222). Gütersloh: Verlag Bertelsmann Stiftung.

Zarzycka, B. (2007). Skala Centralności Religijności S. Hubera [Centrality of Religiosity Scale by S. Huber]. Roczniki Psychologiczne, 10(1), 133-157.

Zarzycka, B. (2011). Polska adaptacja Skali Centralności Religijności S. Hubera [Polish adaptation of the Centrality of Religiosity Scale by S. Huber]. In M. Jarosz (Ed.), Psychologiczny pomiar religijności [Psychological measurement of religiosity] (pp. 231-261). Lublin: Towarzystwo Naukowe KUL.

Zarzycka, B., \& Rydz, E. (2013). Explaining the relationship between Post-critical Beliefs and SOC in Polish young, middle and late adults. Journal of Religion and Health. http://dx.doi.org/10.1007/s10943-013-9680-7.

Zwingmann, C. (1991). Religiosität and Lebenszufriedenheit: Empirische Untersuchungen unter besonderer Berücksichtigung der religiösen Orientierung [Religiosity and satisfaction with life: Empirical studies considering religious orientation]. Regensburg: S. Roderer.

\section{(cc) EY}

This work is licensed under a Creative Commons Attribution 3.0 License. 